\title{
The Use of Digital Technologies at School and Cognitive Learning Outcomes : A Population-Based Study in Finland
}

\section{Saarinen, Aino I. L.}

2021-02

Saarinen , A I L , Lipsanen , J , Hintsanen , M , Huotilainen , M \& Keltikangas-Jarvinen , L 2021, ' The Use of Digital Technologies at School and Cognitive Learning Outcomes : A Population-Based Study in Finland ' , International Journal of Educational Psychology , vol. 10 , no. 1 , pp. 1-26 . https://doi.org/10.17583/ijep.2021.4667

http://hdl.handle.net/10138/330658

https://doi.org/10.17583/ijep.2021.4667

cc_by

publishedVersion

Downloaded from Helda, University of Helsinki institutional repository.

This is an electronic reprint of the original article.

This reprint may differ from the original in pagination and typographic detail.

Please cite the original version. 


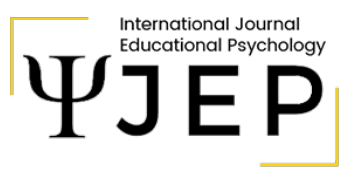

\section{Hipatia Press}

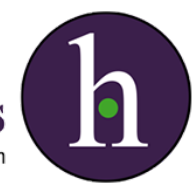

Instructions for authors, subscriptions and further details:

\section{http://ijep.hipatiapress.com/}

\section{The Use of Digital Technologies at School and Cognitive Learning Outcomes: A Population-Based Study in Finland}

Aino I.L. Saarinen ${ }^{1,2}$, Jari Lipsanen ${ }^{2}$, Mirka Hintsanen ${ }^{1}$, Minna Huotilainen $^{2} \&$ Liisa Keltikangas-Järvinen ${ }^{2}$

1) University of Oulu (Finland)

2) University of Helsinki (Finland)

Date of publication: February 24th, 2021

Edition period: February 2021 - June 2021

To cite this article: Saarinen, A., Lipsanen, J.,Hintsanen, M, Huotilainen, M.\& Keltikangas-Järvinen, L. (2021). The Use of Digital Technologies at School and Cognitive Learning Outcomes: A Population-Based Study in Finland International Journal of Educational Psychology, 10(1), 1-26.

https://doi.org/10.17583/ijep.2021.4667

To link this article: http://dx.doi.org/10.17583/ijep.4667

PLEASE SCROLL DOWN FOR ARTICLE

The terms and conditions of use are related to the Open Journal System and to Creative Commons Attribution License(CC-BY). 


\section{The Use of Digital Technologies at School and Cognitive Learning}

\section{Outcomes: A Population-Based Study}

\section{in Finland}

Aino I.L. Saarinen ${ }^{1,2}$, Jari Lipsanen ${ }^{2}$, Mirka Hintsanen ${ }^{1}$, Minna Huotilainen ${ }^{2}$ \& Liisa Keltikangas-Järvinen ${ }^{2}$

\section{1) University of Oulu (Finland)}

2) University of Helsinki (Finland)

\section{Abstract}

Recently, the use of information and communications technology (ICT) at school has been extensively increased in Finland. This study investigated whether the use of ICT at school is linked to students 'learning outcomes in Finland. We used the Finnish PISA 2015 data $(N=5037)$. Cognitive learning outcomes (i.e. science, mathematics, reading, collaborative problem-solving) were evaluated with computer-based tests. ICT use at school, ICT availability at school, and students' perceived ICT competence were assessed with self-rating questionnaires. Frequent ICT use at school predicted students' weaker performance in all the cognitive learning outcomes, when adjusted for age, gender, parental socioeconomic status, students' ICT competence, and ICT availability at school. Further, the effect of ICT use on learning outcomes was more negative in students with higher than lower ICT skills. Frequent use of ICT at school appears to be linked to weaker cognitive learning outcomes in Finland. This may be explained by working memory overload and task-switching during the use of digital technologies. This finding also suggests that even though students with ICT skills are good at mechanical use of digital device, they may not have abilities for a goaloriented and self-directed use of digital technologies that could promote their learning.

Keywords: digital learning, learning outcomes, comprehensive school, teaching practices. 


\section{EI Uso de las Tecnologías en la Escuela y los Resultados del Aprendizaje Cognitivo: Un Estudio basado en la Población en Finlandia}

Aino I.L. Saarinen ${ }^{1,2}$, Jari Lipsanen ${ }^{2}$, Mirka Hintsanen ${ }^{1}$, Minna Huotilaine ${ }^{2} \&$ Lisa Keltikangas-Järvinen ${ }^{2}$

\section{1) University of Oulu (Finland)}

2) University of Helsinki (Finland)

\section{Resumen}

Recientemente, el uso de las tecnologías de la información y la comunicación (TIC) en la escuela ha aumentado considerablemente en Finlandia. Este estudio investigó si el uso de las TIC en la escuela está relacionado con los resultados de aprendizaje de los estudiantes en Finlandia. Los resultados del aprendizaje cognitivo (es decir, ciencias, matemáticas, lectura, resolución de problemas en colaboración) se evaluaron con pruebas informáticas. El uso frecuente de las TIC en la escuela predijo el menor rendimiento de los estudiantes en todos los resultados de aprendizaje cognitivo, cuando se ajustó por edad, género, estatus socioeconómico de los padres, competencia en TIC de los estudiantes y disponibilidad de TIC en la escuela. Además, el efecto del uso de las TIC en los resultados del aprendizaje fue más negativo en los estudiantes con mayores que menores conocimientos de las TIC. El uso frecuente de las TIC en la escuela parece estar relacionado con resultados de aprendizaje cognitivo más débiles en Finlandia. Esto puede explicarse por la sobrecarga de la memoria de trabajo y el cambio de tareas durante el uso de las tecnologías digitales. Estos resultados también sugieren que, aunque los alumnos con conocimientos de TIC son buenos en el uso mecánico de los dispositivos digitales, es posible que no tengan capacidades para un uso orientado a objetivos y autodirigido de las tecnologías digitales que podría promover su aprendizaje.

Palabras clave: aprendizaje digital, resultados del aprendizaje, escuela integral, práctica docente. 
I $\mathrm{n}$ the Finnish educational system, a fundamental goal is to provide all students equal possibilities for school success, from comprehensive even university education includes only minor tuition fees in Finland, in order to ensure that students from low- and high-income backgrounds could achieve academic-level education. In line with this, the basic education legislation in Finland strongly postulates that "teaching methods must promote equality in the society" (Basic Education Act 628/1998). The most recent PISA test in 2015 , however, showed that inequality in educational achievements is rapidly growing in Finland (OECD, 2016). For instance, it has been estimated that even more than 6000 Finnish students do not reach the curricula-related basic skills (OECD, 2016). In particular, the school drop-out of boys and students with low maternal education or immigration background has aroused concern in Finland.

The increasing inequality in learning outcomes is of great societal importance since school drop-out composes a major risk for the accumulation of other risk factors and social marginalization later in life. There is evidence that school failure predicts delinquent behavior, lower socioeconomic status, and social exclusion in adulthood (Chen \& Kaplan, 2003; Kokko et al., 2003). Further, poor school performance is found to predict risky health behavior in adulthood, such as smoking (Bryant et al., 2000), excessive alcohol use (Huurre et al., 2010; Pitkänen et al., 2008) and obesity (Alatupa et al., 2010). Finally, poor school performance also predicts psychiatric symptoms such as depression and suicidality in adulthood (Gunnell et al., 2011; Shochet et al., 2006). Taken together, school drop-out predicts lower social capital and poorer physical and mental health that further exacerbate the risk for social marginalization.

Consequently, there has been a strong political debate about why the inequality in learning outcomes is increasing in Finland. Until now, the reasons have been mostly searched from outside the school system. It has been suggested that limited participation in early childhood education, low maternal education or students' mental health problems might have increased inequality in school performance.

However, it has remained largely uninvestigated whether some factors inside the school system, i.e. some learning practices adopted by the school system, might produce inequality in learning outcomes between students and 
to expose high-risk students to social marginalization. One such factor might be the increasing use of digital technologies at school.

In the recent years, the Finnish government has implemented a program called "Comprehensive school of the digital era" that aims to modernize the learning environments and to widely utilize digital material in learning (Kaarakainen et al., 2017). Additionally, in Helsinki (the capital city of Finland), it has been implemented a program that aims to increase digitalization in the comprehensive school over the years 2016-2019 (School District Office of Helsinki, 2016). The economic investment of the program is $37000000 €$ (School District Office of Helsinki, 2016). The program states that "digitalization enables the use of novel pedagogical methods for learning and teaching as well as new ways of working that will essentially increase educational effectivity, productivity, and efficacy" (School District Office of Helsinki, 2016). Thus, the financial investments to digital learning methods have been enormous in Finland.

Further, the program states that "the best effectivity of digital learning will be reached if the digital reform passes through the whole organizational culture in schools" (School District Office of Helsinki, 2016). Consequently, the degree of digitalization is at a high level in the Finnish schools. For example, even more than $90 \%$ of the Finnish students are estimated to be in highly digitally equipped schools (Wastiau et al., 2013). Despite the enormous economic investments, however, evidence about the association of ICT use at school with students' learning outcomes in Finland is largely lacking.

Previous research about the influence of digital technologies on learning outcomes has included severe methodological limitations (All et al., 2016). Firstly, it has remained vastly without consideration whether implementing ICT use at school as a learning method might have influences on the equality of learning outcomes at the population level. Hence, representative population-based studies have been largely lacking about the link between ICT use and learning outcomes. In many cases, researchers may not have sufficient resources to educate participants for the use of digital technology and various learning applications before the study. Hence, in several studies the participants have consisted of a selective sample of volunteers that are likely to be more digitally-interested and digitally-capable individuals than on average. Secondly, several studies (e.g. Chuang et al., 2009; Martin \& Ertzberger, 2013) have not included a control group that had not used digital technologies but instead some more traditional learning methods. This has 
seriously limited the study conclusions about the effectiveness of digital technologies. Thirdly, when investigating the influence of ICT use on learning outcomes, many studies (Chen et al., 2008; Ronimus et al., 2014) have adopted an experimental design where the details of ICT use have been carefully adjusted. These findings, however, may not likely be generalized to practical school environments. Specifically, it has been emphasized that there exist a variety of practical challenges in how the use of digital technologies is organized in the classroom (Balanskat et al., 2006). There is also variation in single teachers' knowledge about the use of digital technologies at school (Kaarakainen et al., 2017). Consequently, regarding digital technologies, a review concluded that "more robust, scientific research is needed that provides a clearer picture of their true impact" (Wilson et al., 2009).

Importantly, the use of digital learning methods includes a certain type of pedagogical ideology and learning concept. This appears to have remained without sufficient societal awareness in Finland. Specifically, digital learning methods aim to promote student-oriented learning, so that the responsibility for directing student's learning process is largely transferred from teacher to student. In this way, efficient use of digital technologies for learning purposes requires a high level of self-directedness and goal-directedness from the student. In practice, students need good abilities to set their learning goals, to select appropriate digital applications in order to reach their goals, and to maintain their attention in the content of the digital learning material (not merely in the technical use of the device).

Children coming from some backgrounds, however, may not possess these necessary skills for efficient use of digital learning methods. For example, there is evidence that children coming from families with low socioeconomic status have lower levels of executive skills, cognitive control, and working memory capacity (Duncan \& Magnuson, 2012; Hackman et al., 2014; Sarsour et al., 2011). In this way, promoting the use of digital learning methods may simultaneously increase inequality in learning outcomes between children coming from different backgrounds. Previously, it has been found that the use of digital technologies has different effects on the learning outcomes among students with higher and lower cognitive abilities (Kalyuga et al., 2003; Paas et al., 2004; Van Merriënboer \& Ayres, 2005). Moreover, it appears that digital skills are different between children coming from rural and urban regions (Salemink et al., 2017) and between children coming from high- and low-SES families (Andrews, 2008; Tandon et al., 2012). Nevertheless, 
population-based studies (including students with varying backgrounds and varying skill levels) about the link of digital learning methods with learning outcomes are lacking in Finland.

The aim of the present study was to investigate (i) whether the frequency of using information and communications technology (ICT) at school is linked to cognitive learning outcomes in the PISA 2015 test (i.e. reading literacy, mathematical literacy, scientific literacy, and collaborative problem-solving), and (ii) whether the association of ICT use at school with cognitive learning outcomes could be modified by availability of ICT device at school or students' ICT competence. We used the Finnish PISA 2015 data that provides a nationally representative sample of the Finnish 15-year-old students. The age of 15 years is of particular importance in the educational context, because students' learning outcomes at that age largely determine their later educational paths (i.e. whether they apply to occupational school or high school or drop out from the educational track).

\section{Material and Methods}

\section{Participants}

The participants came from the Finnish PISA (Programme for International Student Assessment) 2015 data. The authors of this study did not participate in the data collection process. The PISA samples were selected in two phases. Firstly, it was randomly selected more than 150 Finnish schools that were teaching students within the target age (i.e. students aged between 15 years and 3 months and 16 years and 2 months, and who were at grade 7 or higher at school). Secondly, on average 42 students within the desired age range were randomly selected in each included school.

In Finland, the desired target population of students included 58955 students. Of this target population, $2.8 \%$ of students were excluded. Hence, the final Finnish sample included altogether 5882 students in PISA 2015 test. In this final sample, $0.5 \%$ of the students were at the 7 th grade, $13.6 \%$ at the 8 th grade, $85.7 \%$ at the 9 th grade, and $0.2 \%$ at the 11 th grade. A more detailed report about the design of the PISA 2015 can be found elsewhere (OECD, 2017a).

The most common exclusion criteria at school-level were the following: schools that were geographically unreachable; schools where the organization of the PISA assessment was not possible by practical reasons; and schools that 
included students only from a specific population (e.g. schools for the blind). At student-level, the main exclusion criteria were as follows: students with limited language proficiency and students with an intellectual or functional disability (assessed by a professional).

In the analyses of this study, all the participants who had full data about the study variables were included (age; gender; the index of economic, social, and cultural status; the index of ICT use at school; the index of ICT availability at school; the index of students' perceived ICT competence; scientific literacy; mathematical literacy, reading literacy; and collaborative problem-solving). The sample in the present study included 5037 students.

\section{Measures}

Information and communications technology (ICT). The index of ICT (information and communications technology) use at school was evaluated with 9 self-rating items filled by students. The items measured how often the students used digital devices for the following activities: (i) "at school"; (ii) "using email at school"; (iii) "browsing the Internet for schoolwork"; (iv) "downloading, uploading or browsing material from the school's website (e.g.)"; (v) "posting [their] work on the school's website"; (vi) "playing simulations at school"; (vii) "practicing and drilling, such as for foreign language learning or mathematics"; (viii) "doing homework on a school computer"; and (ix) "using school computers for group work and communication with other students". The items were rated with a 5-point scale ranging from 1 (never or hardly ever) to 5 (every day). A higher value of the index of ICT referred to more frequent use of ICT at school.

The index of students' perceived ICT competence was assessed with 5 items rated by students. The items were the following: (i) "I feel comfortable using digital devices that I am less familiar with"; (ii) "If my friends and relatives want to buy new digital devices or applications, I can give them advice"; (iii) "I feel comfortable using my digital devices at home"; (iv) "When I come across problems with digital devices, I think I can solve them"; and (v) "If my friends and relatives have a problem with digital devices, I can help them". The items were rated with a 5-point scale ranging from 1 (strongly disagree) to 5 (strongly agree). The index was scaled so that a higher value indicated a higher perceived competence with ICT.

The index of ICT availability at school was evaluated with a 10-item questionnaire filled by students. The questions measured whether the 
following digital devices were available at school: (i) desktop computer; (ii) portable laptop or notebook; (iii) tablet computer; (iv) internet connected school computers; (v) internet connection via wireless network; (vi) storage space for school-related data; (vii) USB (memory) stick; (viii) ebook reader; (ix) data projector; or (x) interactive whiteboard. The items were answered with a 3-point scale (1="Yes, and I use it"; $2=$ "Yes, but I do not use it"; $3=$ "No"). The total score of the questionnaire was scaled so that a higher value referred to higher ICT availability of the school.

All the ICT indices were standardized with the mean of 0 and standard deviation of 1 across the OECD countries. The measurement of ICT indexes is more precisely described elsewhere (OECD, 2017b).

Cognitive learning outcomes. The measurement of cognitive learning outcomes (scientific literacy, reading literacy, mathematical literacy, and collaborative problem-solving) included altogether 810 minutes of test items. The students performed various combinations of the test items. For each student, it was selected a 2-hour-long test pattern including four pieces of 30minute clusters: two clusters in the field of scientific literacy and the other clusters in the fields of reading literacy, mathematical literacy, and collaborative problem solving. All the items were rated with one of the following rating types: closed constructed-response (e.g. writing a single number), open constructed-response (a slightly longer written response), or multiple choice-response (selecting one or more responses from a response set). Further, all the items of PISA 2015 were performed with computer-based tests. The measurement design of the cognitive learning outcomes is described with more detail elsewhere (OECD, 2017b).

Scientific literacy measured students 'abilities (i) to explain phenomena in a scientific way (in the fields of biology, physics, chemistry, and space sciences), (ii) to assess and design necessary steps in scientific investigations (e.g. to define dependent and independent variables, control variables, and methods to decrease measurement error), and (iii) to interpret and reflect evidence scientifically (to differentiate between scientific hypotheses, observations, and facts).

Reading literacy did not measure the most basic reading skills. Instead, reading literacy assessed the student's capacity to understand, interpret, integrate, and reflect the content of different types of texts. The text types consisted of continuous texts (e.g. chapters, books), non-continuous text materials (e.g. lists, tables, graphs, advertisements, indexes) and combinations 
between them. The texts were placed in personal, occupational, educational, and public contexts, so that the items measured students' abilities to apply their reading skills in various of daily events.

Mathematical literacy referred to students' abilities (i) to formulate contextualized problems into mathematical form, (ii) to employ necessary mathematical computations to solve the problems that have been formulated mathematically (e.g. mental calculation, spatial visualization, modeling mathematical change with appropriate functions), and (iii) to interpret the mathematical results, for example, to apply the solutions in various every-day contexts, to evaluate the reasonableness of the results, and to acknowledge the uncertainty of measurements.

Collaborative problem-solving measured students' abilities (i) to establish and maintain shared understanding about the task with others, (ii) to take the necessary collaborative steps to solve the problem, and (iii) to create and maintain collaborative organization (so that each group member's knowledge could be utilized). Collaborative problem-solving was evaluated with computer-based items where each student was collaborating with computer agents.

The index of economic, social and cultural status (ESCS). The index of ESCS was assessed with questionnaires presented for students. The index of ESCS included three factors: (1) highest parental education, (2) highest parental occupation, and (3) family wealth. Parental education was rated with a 7-point scale ranging from 0 (no education) to 6 (theoretically oriented tertiary and post-graduate) on the basis of the International Standard Classification of Education (ISCED) 1997 (OECD, 1999). Parental occupational status was assessed with of the International Standard Classification of Occupations (ISCO-08). Family wealth was assessedwith19 household items measuring, for example, the number of room space, books, works of art, and electronic devices at home. Finally, the index of ESCS was scaled with the mean of 0 and standard deviation of 1 between the OECD countries. A more precise description of the index of ESCS is available elsewhere (OECD, 2017a).

\section{Statistical analyses}

The data were analyzed with structural equation models (run with STATA version 15.0). Students' performance in each cognitive learning outcome was treated as latent factor with 10 plausible values, which were based on Rasch 
Model, as indicator (manifest) variables. More detailed information about the estimation of the plausible values can be found elsewhere (OECD, 2017a). A separate structural equation model was estimated for each cognitive learning outcome (i.e. scientific literacy, mathematical literacy, reading literacy, collaborative problem-solving). In models 1 , we investigated whether the use of ICT is associated with cognitive learning outcomes. Age, gender, and the index of ESCS were controlled for. In models 2, we investigated whether the association of use of ICT with cognitive learning outcomes might be sustained after controlling for the availability of ICT at school and the students' perceived ICT competence. Hence, we added to the predictors the availability of ICT at school and the students' perceived ICT competence. In models 3, we investigated whether the association of ICT use at school with cognition learning outcomes was modified by the students' ICT competence. That is, in models 3, we added the interaction effect between ICT use at school and students' ICT competence in the model. In models 4, we examined whether the association of ICT use at school with cognitive learning outcomes was modified by the availability of ICT at school. Specifically, in models 4, we added the interaction effect between ICT use at school and students' ICT competence in the model.

The goodness-of-fit of the structural equation models was assessed with the values of the Root-Mean-Square Error of Approximation (RMSEA), the Comparative Fit Index (CFI), and the Tucker Lewis Index (TLI). It has been showed that the value of RMSEA should be less than 0.06 and the CFI and the TLI should be more than 0.95 (Hu \& Bentler, 1999). Additionally, lower values of the $\chi^{2}$ test of absolute model fit suggest better model fit to the data (Schreiber et al., 2006).

\section{Results}

Descriptive statistics of the study variables are shown in Table 1. 
Table 1.

Means, frequencies, standard deviations, and ranges of the study variables.

\begin{tabular}{llll}
\hline & Mean / Frequency (\%) & SD & Range \\
\hline Age & 15.72 & 0.28 & $15.25 ; 16.25$ \\
Gender & & & \\
$\quad$ Female & $2524(50.1)$ & & \\
$\quad$ Male & $2513(49.9)$ & & \\
Index of ESCS & 0.28 & 0.74 & $-2.91 ; 3.57$ \\
ICT use at school & 0.10 & 0.72 & $-1.67 ; 3.63$ \\
ICT availability at school & 6.92 & 2.09 & $0.00 ; 10.00$ \\
Students' ICT competence & -0.08 & 0.90 & $-2.71 ; 1.94$ \\
Scientific literacy & 1 & 88.68 & $248.63 ; 793.90$ \\
Mathematical literacy $^{1}$ & 539.97 & 73.09 & $249.64 ; 737.36$ \\
Reading literacy $^{1}$ & 518.34 & 82.60 & $179.26 ; 749.70$ \\
Collaborative problem-solving $^{1}$ & 537.12 & 87.24 & $157.77 ; 833.18$ \\
\hline
\end{tabular}

${ }^{1}$ The mean of the plausible values $1-10$.

Table 2 shows the results when examining the association of ICT use at school with students' cognitive learning outcomes. The results revealed that frequent use of ICT at school was associated with weaker performance in all the cognitive outcomes, i.e. lower scores of scientific literacy, mathematical literacy, reading literacy, and collaborative problem-solving (Models 1). All these associations were controlled for age, gender, and the index of economic, social, and cultural status (ESCS). When adjusted also for the availability of ICT at school and students' perceived ICT competence, all the significant associations of use of ICT at school with weaker performance in cognitive outcomes remained the same (Models 2). Further analyses revealed that there were no significant interaction effects between age and ICT use at school, when cognitive learning outcomes were set as dependent variable. Additionally, all the associations of ICT use at school and cognitive learning outcomes were evident among males and females. 


\section{Saarinen et al.,--Digital learning at school}

Table 2.

The standardized coefficients (B) with 95\% confidence intervals of the ICT variables, when predicting students' performance in scientific literacy, mathematical literacy, reading literacy, and collaborative problem-solving with structural equation models.

\begin{tabular}{|c|c|c|c|c|}
\hline & \multicolumn{2}{|c|}{ Model 1} & \multicolumn{2}{|c|}{ Model 2} \\
\hline & $\overline{\mathrm{B}}$ & $95 \% \mathrm{CI}$ & $\bar{B}$ & $95 \% \mathrm{CI}$ \\
\hline \multicolumn{5}{|l|}{ Scientific literacy } \\
\hline Age & $0.061 * * *$ & $0.035 ; 0.086$ & $0.060 * * *$ & $0.034 ; 0.085$ \\
\hline Gender $^{\mathrm{a}}$ & $-0.065 * * *$ & $-0.091 ;-0.039$ & $-0.091 * * *$ & $-0.12 ;-0.065$ \\
\hline Index of ESCS & $0.33 * * *$ & $0.30 ; 0.35$ & $0.32 * * *$ & $0.30 ; 0.35$ \\
\hline ICT use at school & $-0.14 * * *$ & $-0.16 ;-0.11$ & $-0.16 * * *$ & $-0.19 ;-0.13$ \\
\hline ICT availability at school & & & -0.0095 & $-0.036 ; 0.017$ \\
\hline Students' ICT competence & & & $0.11 * * *$ & $0.085 ; 0.14$ \\
\hline \multicolumn{5}{|l|}{ Mathematical literacy } \\
\hline Age & $0.054 * * *$ & $0.028 ; 0.079$ & $0.052 * * *$ & $0.027 ; 0.078$ \\
\hline Gender $^{\mathrm{a}}$ & -0.0063 & $-0.032 ; 0.020$ & $-0.034 *$ & $-0.060 ;-0.0070$ \\
\hline Index of ESCS & $0.37 * * *$ & $0.35 ; 0.39$ & $0.36 * * *$ & $0.34 ; 0.39$ \\
\hline ICT use at school & $-0.11 * * *$ & $-0.14 ;-0.083$ & $-0.13 * * *$ & $-0.16 ;-0.10$ \\
\hline ICT availability at school & & & -0.016 & $-0.042 ; 0.011$ \\
\hline Students' ICT competence & & & $0.12 * * *$ & $0.093 ; 0.15$ \\
\hline \multicolumn{5}{|l|}{ Reading literacy } \\
\hline Age & $0.068 * * *$ & $0.043 ; 0.093$ & $0.067 * * *$ & $0.042 ; 0.092$ \\
\hline Gendera & $-0.24 * * *$ & $-0.26 ;-0.21$ & $-0.27 * * *$ & $-0.29 ;-0.24$ \\
\hline Index of ESCS & $0.33^{* * *}$ & $0.30 ; 0.35$ & $0.32 * * *$ & $0.30 ; 0.34$ \\
\hline ICT use at school & $-0.13 * * *$ & $-0.16 ;-0.11$ & $-0.15 * * *$ & $-0.18 ;-0.13$ \\
\hline ICT availability at school & & & -0.016 & $-0.042 ; 0.0092$ \\
\hline Students' ICT competence & & & $0.13 * * *$ & $0.094 ; 0.15$ \\
\hline
\end{tabular}


Table 2. (Continued)

The standardized coefficients (B) with 95\% confidence intervals of the ICT variables, when predicting students' performance in scientific literacy, mathematical literacy, reading literacy, and collaborative problem-solving with structural equation models.

\begin{tabular}{|c|c|c|c|c|}
\hline & \multicolumn{2}{|c|}{ Model 1} & \multicolumn{2}{|c|}{ Model 2} \\
\hline & $\mathrm{B}$ & $95 \% \mathrm{CI}$ & $\mathrm{B}$ & $95 \% \mathrm{CI}$ \\
\hline \multicolumn{5}{|c|}{ Collaborative problem-solving } \\
\hline Age & $0.066 * * *$ & $0.04 ; 0.092$ & $0.065 * * *$ & $0.040 ; 0.091$ \\
\hline Gender $^{\mathrm{a}}$ & $-0.25 * * *$ & $-0.27 ;-0.22$ & $-0.27 * * *$ & $-0.29 ;-0.24$ \\
\hline Index of ESCS & $0.27 * * *$ & $0.25 ; 0.29$ & $0.27 * * *$ & $0.24 ; 0.29$ \\
\hline ICT use at school & $-0.13 * * *$ & $-0.16 ;-0.11$ & $-0.15 * * *$ & $-0.18 ;-0.12$ \\
\hline ICT availability at school & & & -0.0036 & $-0.030 ; 0.023$ \\
\hline Students' ICT competence & & & $0.083 * * *$ & $0.056 ; 0.11$ \\
\hline
\end{tabular}

$* \mathrm{p}<.05 * * * \mathrm{p}<.001{ }^{\text {a }}$ Female as the reference group. ICT $=$ Information and communications technology. The index of ESCS $=$ The index of economic, social, and cultural status.

Model 1: Adjusted with baseline covariates (age, gender, the index of ESCS).

Model 2: Adjusted also with ICT availability at school and students' ICT competence.

Next, we investigated whether the associations of ICT use at school with cognitive learning outcomes could be moderated by ICT availability at school or students' perceived ICT competence. The findings are shown in Table 3. When cognitive learning outcomes were set as the dependent variable, use of ICT at school had significant negative interaction effects of with (i) student's perceived ICT competence and (ii) ICT availability at school. The negative main effect of ICT use on cognitive learning outcomes was significant after adding its interaction with students' ICT competence to the model. Instead, after adding the interaction between ICT use and ICT availability at school, the main effect of ICT on cognitive learning outcomes was not significant. Taken together, the findings indicated that frequent ICT use was associated with students' weaker cognitive learning outcomes at all levels of students' ICT competence, but this association was more evident at high levels than low levels of students' ICT competence (see Figure 1). Further, frequent ICT use at school was associated with students' weaker cognitive learning outcomes at high levels but not at low levels of ICT availability at school. 


\section{Saarinen et al.,--Digital learning at school}

Table 3.

The standardized coefficients (B) with 95\% confidence intervals of the ICT variables, when predicting students' learning outcomes with structural equation models.

\begin{tabular}{|c|c|c|c|c|}
\hline & \multicolumn{2}{|c|}{ Model 3} & \multicolumn{2}{|c|}{ Model 4} \\
\hline & $\mathrm{B}$ & $95 \% \mathrm{CI}$ & $\mathrm{B}$ & $95 \% \mathrm{CI}$ \\
\hline \multicolumn{5}{|l|}{ Scientific literacy } \\
\hline Age & $0.062 * * *$ & $0.036 ; 0.088$ & $0.060 * * *$ & $0.034 ; 0.085$ \\
\hline Gender $^{\mathrm{a}}$ & $-0.090 * * *$ & $-0.12 ;-0.064$ & $-0.089 * * *$ & $-0.12 ;-0.062$ \\
\hline Index of ESCS & $0.32 * * *$ & $0.30 ; 0.35$ & $0.32 * * *$ & $0.30 ; 0.35$ \\
\hline ICT use at school & $-0.15 * * *$ & $-0.18 ;-0.12$ & -0.057 & $-0.13 ; 0.014$ \\
\hline ICT availability at school & -0.012 & $-0.038 ; 0.015$ & -0.0060 & $-0.033 ; 0.021$ \\
\hline Students' ICT competence & $0.12 * * *$ & $0.094 ; 0.15$ & $0.11 * * *$ & $0.084 ; 0.14$ \\
\hline ICT use at school * Students' ICT competence & $-0.073 * * *$ & $-0.099 ;-0.046$ & & \\
\hline ICT use at school * ICT availability at school & & & $-0.11 * *$ & $-0.18 ;-0.038$ \\
\hline \multicolumn{5}{|l|}{ Mathematical literacy } \\
\hline Age & $0.055 * * *$ & $0.029 ; 0.080$ & $0.052 * * *$ & $0.027 ; 0.078$ \\
\hline Gender $^{\mathrm{a}}$ & $-0.033^{*}$ & $-0.059 ;-0.0061$ & $-0.032 *$ & $-0.058 ;-0.0050$ \\
\hline Index of ESCS & $0.26^{* * *}$ & $0.34 ; 0.39$ & $0.36^{* * *}$ & $0.34 ; 0.39$ \\
\hline ICT use at school & $-0.12 * * *$ & $-0.15 ;-0.093$ & -0.045 & $-0.12 ; 0.027$ \\
\hline ICT availability at school & -0.018 & $-0.044 ; 0.0082$ & -0.013 & $-0.039 ; 0.014$ \\
\hline Students' ICT competence & $0.13 * * *$ & $0.10 ; 0.16$ & $0.12 * * *$ & $0.092 ; 0.15$ \\
\hline ICT use at school * Students' ICT competence & $-0.074 * * *$ & $-0.10 ;-0.048$ & & \\
\hline ICT use at school * ICT availability at school & & & $-0.091 *$ & $-0.16 ; 0.019$ \\
\hline \multicolumn{5}{|l|}{ Reading literacy } \\
\hline Age & $0.069 * * *$ & $0.044 ; 0.094$ & $0.067 * * *$ & $0.042 ; 0.092$ \\
\hline Gender & $-0.26 * * *$ & $-0.29 ;-0.24$ & $-0.26 * * *$ & $-0.29 ;-0.24$ \\
\hline Index of ESCS & $0.32 * * *$ & $0.30 ; 0.34$ & $0.32 * * *$ & $0.30 ; 0.34$ \\
\hline ICT use at school & $-0.14 * * *$ & $-0.17 ;-0.12$ & -0.011 & $-0.081 ; 0.058$ \\
\hline ICT availability at school & -0.019 & $-0.044 ; 0.0067$ & -0.012 & $-0.037 ; 0.014$ \\
\hline Students' ICT competence & $0.13 * * *$ & $0.10 ; 0.16$ & $0.12 * * *$ & $0.093 ; 0.14$ \\
\hline ICT use at school * students' ICT competence & $-0.079 * * *$ & $-0.10 ;-0.054$ & & \\
\hline ICT use at school $*$ ICT availability at school & & & $-0.15 * * *$ & $0.22 ;-0.082$ \\
\hline
\end{tabular}


Table 3. (continued)

The standardized coefficients (B) with 95\% confidence intervals of the ICT variables, when predicting students' learning outcomes with structural equation models.

\begin{tabular}{|c|c|c|c|c|}
\hline & \multicolumn{2}{|c|}{ Model 3} & \multicolumn{2}{|c|}{ Model 4} \\
\hline & $\mathrm{B}$ & $95 \% \mathrm{CI}$ & $\mathrm{B}$ & $95 \% \mathrm{CI}$ \\
\hline \multicolumn{5}{|l|}{ Collaborative problem-solving } \\
\hline Age & $0.067 * * *$ & $0.042 ; 0.093$ & $0.065 * * *$ & $0.040 ; 0.091$ \\
\hline Gender & $-0.27 * * *$ & $-0.29 ;-0.24$ & $-0.26 * * *$ & $-0.29 ;-0.24$ \\
\hline Index of ESCS & $0.26 * * *$ & $0.24 ; 0.29$ & $0.26^{* * *}$ & $0.24 ; 0.29$ \\
\hline ICT use at school & $-0.14 * * *$ & $-0.17 ;-0.11$ & -0.012 & $-0.082 ; 0.060$ \\
\hline ICT availability at school & -0.0056 & $-0.032 ; 0.021$ & 0.0011 & $-0.025 ; 0.028$ \\
\hline Students' ICT competence & $0.090 * * *$ & $0.063 ; 0.12$ & $0.081 * * *$ & $0.054 ; 0.11$ \\
\hline ICT use at school $*$ Students' ICT competence & $-0.064 * * *$ & $-0.091 ;-0.038$ & & \\
\hline ICT use at school * ICT availability at school & & & $-0.15 * * *$ & $-0.22 ;-0.077$ \\
\hline
\end{tabular}

$* \mathrm{p}<.01 * * * \mathrm{p}<.001{ }^{\text {a }}$ Female as the reference group.ICT $=$ Information and communications technology.

Model 1: The interaction between ICT use at school and students' ICT competence was added to the model. Model 2: The interaction between ICT use at school and ICT availability was added to the model.

Figure 1.a)

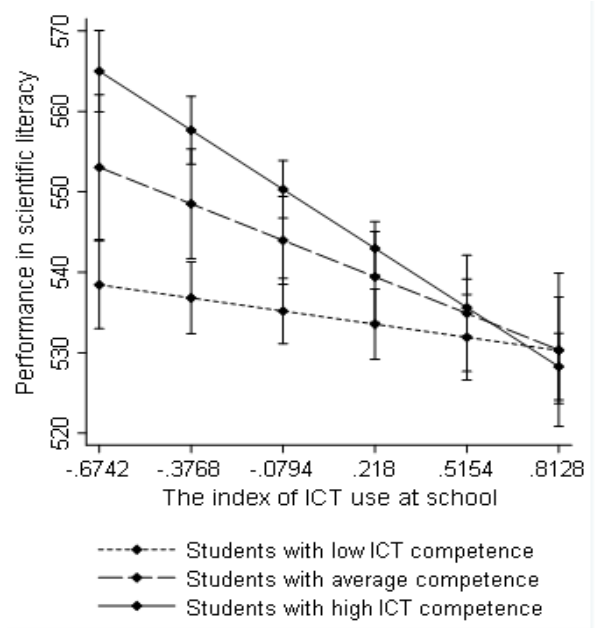




\section{Saarinen et al.,--Digital learning at school}

Figure 1.b)

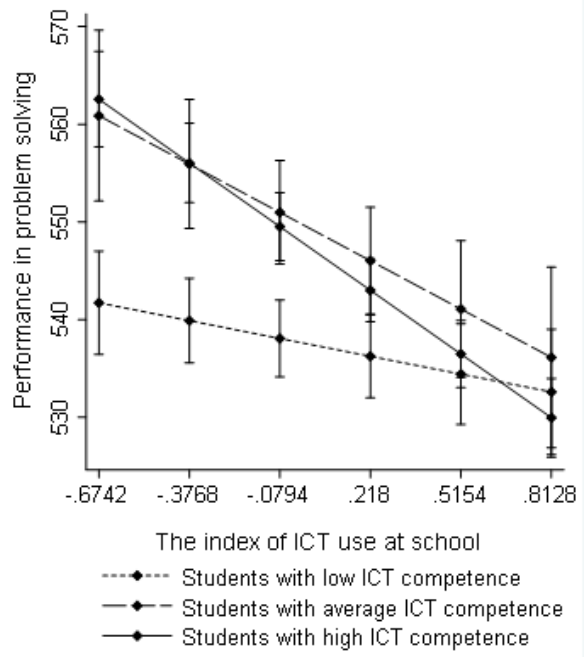

Figure 1.c)

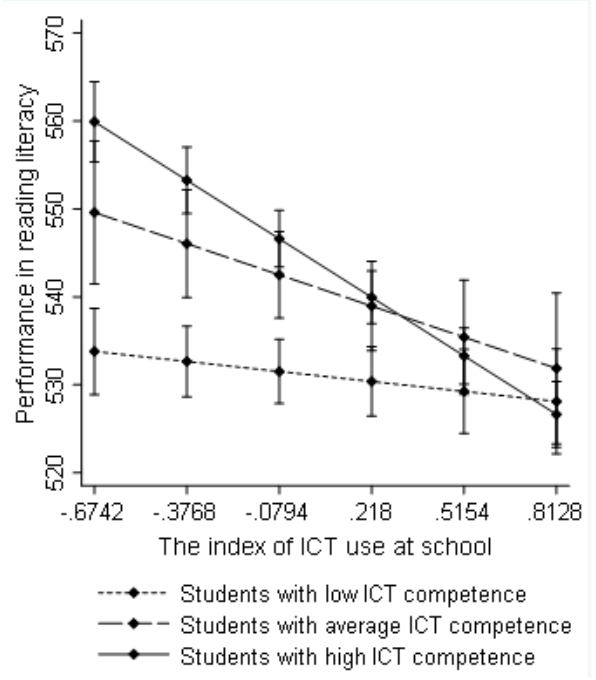

Figure 1.d) 


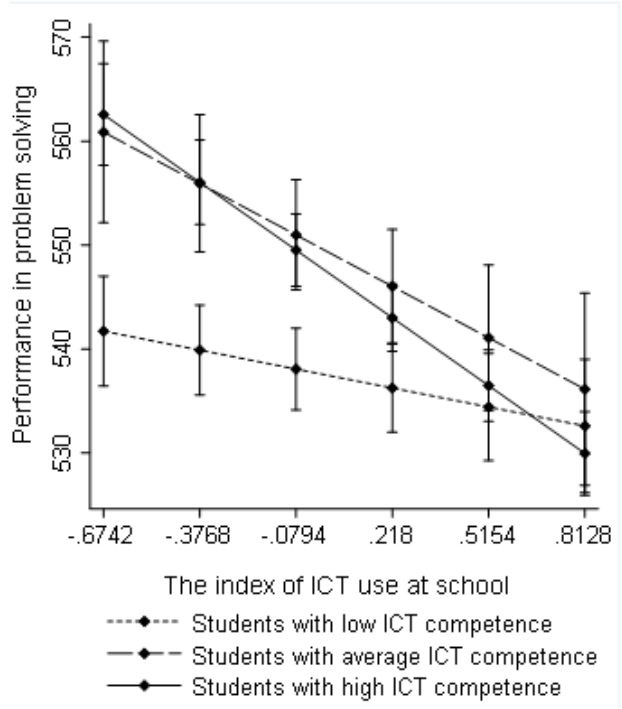

Figure 1. Predicted marginal means with 95\% confidence intervals of students' performance in scientific literacy (a), mathematical literacy (b), reading literacy (c), and collaborative problem solving (d) at different levels of ICT use at school (ranging from 10th percentile to 90th percentile) and among students with low (lowest 30\%), average, and high (highest 30\%) ICT competence. Adjusted for age, gender, the index of ESCS, and availability of ICT at school.

The goodness-of-fit statistics of the models are presented in Supplementary Material. The goodness-of-fit of the models was found to be excellent $(\mathrm{CFI}=[0.998 ; 1.000] ; \mathrm{TLI}=[0.998 ; 1.000] ; \mathrm{RMSEA}=[0.001 ; 0.00017]$ in all the models).

\section{Discussion}

It was found that frequent use of digital technologies (ICT) at school was associated with weaker cognitive performance in the PISA 2015 test in Finland, i.e. lower scores in scientific literacy, mathematical literacy, reading literacy, and collaborative problem-solving. Further, the negative association of frequent ICT use at school with learning outcomes was more negative 


\section{Saarinen et al.,--Digital learning at school}

among students with high than low ICT competence. Moreover, the association of frequent ICT use at school with weaker cognitive learning outcomes was more evident at high than low levels of availability of ICT device at school. Taken together, the findings indicate that the negative association of ICT use with cognitive learning outcomes may not be mitigated by increasing students' ICT competence or the availability of ICT device at school. All the associations were sustained after controlling for age, gender, and the index of economic, social, and cultural status.

The association of frequent ICT use with weaker cognitive performance in the PISA 2015 is highly in line with previous studies conducted in other countries. For example, it has been found that frequent computer use in classroom (Carter et al., 2017; Fried, 2008, Hembrooke \& Gay, 2003) and writing notes with computer rather than by hand (Mueller \& Oppenheimer, 2014) are linked with weaker school performance. Additionally, several studies have found no effect of digital technologies on students' academic achievements (Yang, 2012). Importantly, it has also been demonstrated that using a laptop during a lesson predicts weaker learning outcomes both for the laptop-user and also for the other students who can view their peer using a laptop (Sana et al., 2013). Hence, one student using ICT in a classroom may negatively affect the learning of several other students, too.

The negative association between ICT use at school and weaker learning outcomes may likely be accounted for by working memory overload. Specifically, the most important phase of learning occurs in working memory. Using working memory, a student selects relevant pieces of information from the learning material, compares them to the previous knowledge, and organizes the new pieces of information into coherent schemas $(26,41)$. Next, the new schemas can be moved to the long-term memory, where a learner can retain the new information later when needed (Van Merriënboer \&Ayres, 2005; Kirschner, 2002). Importantly, however, the working memory has a highly limited capacity, so that overloading working memory substantially reduces the opportunities for efficient learning (Kalyuga et al., 2003; Kirschner, 2002; Mayer \& Moreno, 1998).

The use of digital technologies is suggested to compose a substantial strain for the working memory in many cases (Kirschner \& Bruyckere, 2017). That is, the use of digital learning applications requires a variety of cognitive tasks, such as processing the content of the learning material, the technical handling of the device, listening to teachers' guidelines, and cognitive inhibition of 
using the device for personal purposes (e.g. social media). However, since multitasking is not possible for the cognitive architecture of the human brain (Kirschner \& Bruyckere, 2017; Sweller et al., 2011), different tasks compete with each other for the limited resources of the working memory, so that performing one cognitive task interferes with concentrating on the other tasks (Kirschner \& Bruyckere, 2017). Hence, use of digital learning applications may result in continuous task-switching, where resources are not available for the content of the learning material (Kirschner \& Bruyckere, 2017). As a result, new information may not be moved to the long-term memory.

Furthermore, the content of digital learning material may impose a severe strain for working memory. That is, most digital learning applications are characterized by a large amount of interacting elements (Van Merriënboer \& Ayres, 2005). For example, a single learning task may simultaneously include verbal and pictorial, auditory and visual, dynamic and static pieces of information. Moreover, in many cases, digital learning applications may not allow a learner to process the information freely, but some pieces of the information may appear and disappear from the screen in accord with the digital learning application. Hence, processing the digital learning material may overload working memory and result in less efficient learning outcomes (Kalyuga et al., 2003; Van Merriënboer \& Ayres, 2005; Kirschner, 2002).

Previously, it has been suggested that the lack of students 'competence in using technical devices for learning purposes might explain some negative findings related to the use of ICT at school (Carter et al., 2017). However, our findings did not provide support for this suggestion. On the contrary, frequent ICT use at school predicted weaker cognitive learning outcomes especially among students with high ICT competence. This is in line with previous evidence. For example, it has been shown that children coming from families with low socioeconomic status are more prone to excessive screen time, media access, or computer playing (Andrews, 2008; Tandon et al., 2012) but, simultaneously, more prone to weaker learning outcomes (OECD, 2016) and lower working memory capacity (Hackman et al., 2014). In this light, the level of students' ICT skills may reflect inequalities in their family background. Hence, it is of utmost importance to consider that although students with high ICT skills are good at mechanical use of digital device, they may not necessarily have abilities for a goal-oriented and self-directed use of digital technologies that could have positive influences on their learning. For example, students with high ICT competence (i.e. better knowledge about the 
use of applications, games, and websites) may be more prone to use the device for other than learning purposes. Taken together, students with high ICT skills may be more likely to come from families with low socioeconomic status and, hence, to belong to the risk group for weaker school success.

In the present study, there were some methodological limitations that are necessary to take into consideration. Specifically, cognitive learning outcomes (i.e. mathematical literacy, scientific literacy, reading literacy, and collaborative problem-solving) were assessed using computer-based tests. Hence, students' skills in using digital technologies may potentially have confounded the performance in cognitive test items. However, when developing the PISA 2015 tests, the aim was to minimize the amount of computer skills needed for conducting the test items (OECD, 2017b). Moreover, students had the possibility to practice the computer-based items and different response formats before starting the test (OECD, 2017b). Overall, the potential effect of students' ICT skills on the test performance in the PISA 2015 has been estimated to be minor (OECD, 2017a). In addition, in our study, the association of the ICT use at school with cognitive learning outcomes sustained even after controlling for students' perceived competence with ICT use. Finally, since the PISA data is cross-sectional, the results do not allow for making any firm conclusions about temporal or causal relationships.

This study had also a variety of substantial strengths. Firstly, we had a comparatively large sample $(N=5037)$ that was representative of the Finnish population of 15-year-old students. Hence, the data provided exceptional possibilities to investigate link of ICT use with learning outcomes in a population-based sample. Secondly, cognitive learning outcomes were evaluated with internationally standardized and objective tests, without any bias deriving from, for example, teacher's rating. Thirdly, we could take into account several potential confounders, such as age, gender, the index of ESCS, students' ICT competence, and availability of ICT at school. Finally, this topic is of particular importance in Finland since in the recent years, extensive economic investments have been implemented in ICT use at school in Finland.

In conclusion, this study found that frequent use of ICT at school is linked with weaker performance in mathematical literacy, scientific literacy, reading literacy, and collaborative problem-solving among 15-year-old students in Finland. This may be explained by working memory overload and taskswitching during the use of digital technologies. Further, we found that the 
association of frequent ICT use with weaker learning outcomes was more evident in students with higher than lower ICT skills. This suggests that although students with high ICT skills are good at mechanical use of digital device, they may not necessarily have abilities for a goal-oriented and selfdirected use of digital technologies that could promote their learning.

\section{References}

Alatupa, S., Pulkki-Råback, L., Hintsanen, M., Ravaja, N., Raitakari, O. T., Telama, R., Viikari, J. S. A., \& Keltikangas-Järvinen, L. (2010). School performance as a predictor of adulthood obesity: a 21-year follow-up study. European Journal of Epidemiology, 25, 267-274. https://doi.org/10.1007/s10654-010-9428-6

All, A., Castellar, E. P. N., \& Van Looy, J. (2016). Assessing the effectiveness of digital game-based learning: Best practices. Computers \& Education, 92, 90-103. https://doi.org/10.1016/j.compedu.2015.10.007 Andrews, G. G. (2008). Gameplay, gender, and socioeconomic status in two American high schools. E-learning and Digital Media, 5, 199-213. https://doi.org/10.2304/elea.2008.5.2.199

Balanskat, A., Blamire, R., \& Kefala, S. (2006). The ICT impact report: A review of studies of ICT impact on schools in Europe. Brussels, European Schoolnet.

Basic Education Act 628/1998 (1998). Parliament of Finland, Helsinki, Finland.

Bryant, A. L., Schulenberg, J.,Bachman, J. G., O'Malley, P. M., \& Johnston, L. D. (2000). Understanding the links among school misbehavior, academic achievement, and cigarette use: A national panel study of adolescents. Prevention Science, 1, 71-87. https://doi.org/10.1023/A:1010038130788

Carter, S. P.,Greenberg, K., \& Walker, M. S. (2017). The impact of computer usage on academic performance: Evidence from a randomized trial at the United States Military Academy. Economics of Education Review, 56, 118-132. https://doi.org/10.1016/j.econedurev.2016.12.005

Chen, Z. Y., \& Kaplan, H. B. (2003). School failure in early adolescence and status attainment in middle adulthood: A longitudinal study. Sociology of Education, 110-127. https://doi.org/10.2307/3090272

Chen, W. F., Wu, W. H., \& Su, T. J. (2008). Assessing virtual laboratories in a digital-filter design course: An experimental study. IEEE Transactions 
on Education, 51, 10-16.

https://doi.org/https://doi.org/10.1109/TE.2007.893353

Chuang, T.-Y. \& Chen, W.-F. (2009). Effect of Computer-Based Video

Games on Children: An Experimental Study. Educational Technology \& Society, 12, 1-10.

Duncan, G. J., \& Magnuson, K. (2012). Socioeconomic status and cognitive functioning: moving from correlation to causation. Wiley

Interdisciplinary Reviews: Cognitive Science, 3, 377-386.

Fried, C. B. (2008). In-class laptop use and its effects on student

learning. Computers \& Education, 50, 906-

914.https://doi.org/10.1016/j.compedu.2006.09.006

Gunnell, D., Löfving, S., Gustafsson, J. E., \& Allebeck, P. (2011). School performance and risk of suicide in early adulthood: follow-up of two national cohorts of Swedish schoolchildren. Journal of Affective Disorders, 131, 104-112. https://doi.org/10.1016/j.jad.2011.01.002

Hackman, D. A., Betancourt, L. M., Gallop, R., Romer, D., Brodsky, N. L., Hurt, H., \& Farah, M. J. (2014). Mapping the trajectory of socioeconomic disparity in working memory: Parental and neighborhood factors. Child Development, 85, 1433-1445. https://doi.org/10.1111/cdev.12242

Hembrooke, H., \& Gay, G. (2003). The laptop and the lecture: The effects of multitasking in learning environments. Journal of Computing in Higher Education, 15, 46-64. https://doi.org/10.1007/BF02940852

Hu, L. T., \& Bentler, P. M. (1999). Cutoff criteria for fit indexes in covariance structure analysis: Conventional criteria versus new alternatives. Structural Equation Modeling: A Multidisciplinary Journal, 6, 1-55.

Huurre, T., Lintonen, T., Kaprio, J., Pelkonen, M., Marttunen, M., \& Aro, H. (2010). Adolescent risk factors for excessive alcohol use at age 32 years. A 16-year prospective follow-up study. Social Psychiatry and Psychiatric Epidemiology, 45, 125-134. https://doi.org/10.1007/s00127-009-0048-

Kaarakainen, M.-T., Kaarakainen, S. S., Tanhua-Piiroinen, E., Viteli, J., Syvänen, A., \& Kivinen, A.(2017). Digiajan peruskoulu 2017 Tilannearvio ja toimenpidesuositukset. Valtioneuvoston selvitys- ja tutkimustoiminnan julkaisusarja, 72/2017.

Kalyuga, S., Ayres, P., Chandler, P., \& Sweller, J. (2003). The expertise reversal effect. Educational Psychologist, 38, 23-31.

https://doi.org/10.4018/978-1-60566-048-6.ch003 
Kirschner, P. A. (2002). Cognitive load theory: Implications of cognitive load theory on the design of learning.Learning and Instruction, 12, 1-10. https://doi.org/10.1016/S0959-4752(01)00014-7

Kirschner, P. A., \& De Bruyckere, P. (2017). The myths of the digital native and the multitasker. Teaching and Teacher Education, 67, 135-142.

Kokko, K., Bergman, L. R., \& Pulkkinen, L. (2003). Child personality characteristics and selection into long-term unemployment in Finnish and Swedish longitudinal samples. International Journal of Behavioral Development, 27, 134-144.

https://doi.org/10.1080\%2F01650250244000137

Martin, F. \&Ertzberger, J. (2013). Here and now mobile learning: An experimental study on the use of mobile technology. Computers \& Education, 68, 76-85. https://doi.org/10.1016/j.compedu.2013.04.021 Mayer, R. E., \& Moreno, R. (1998). A split-attention effect in multimedia learning: Evidence for dual processing systems in working memory. Journal of Educational Psychology, 90, 312.

Mueller, P. A. \& Oppenheimer, D. M. (2014). The pen is mightier than the keyboard: Advantages of longhand over laptop note taking. Psychological Science, 25, 1159-1168.

https://doi.org/10.1177/0956797614524581

Organisation for Economic Co-operation and Development (OECD) (1999).

Classifying Educational Programmes: Manual for ISCED-97

Implementation in OECD Countries. OECD Publishing, Paris.

Organisation for Economic Co-operation and Development (OECD) (2016).

PISA 2015 Results (Volume I): Excellence and Equity in Education,

PISA. Paris: OECD Publishing, Paris.

Organisation for Economic Co-operation and Development (OECD)

(2017a). PISA 2015 Technical Report. PISA, OECD Publishing, Paris.

Organisation for Economic Co-operation and Development (OECD)

(2017b). PISA 2015 Assessment and Analytical Framework: Science,

Reading, Mathematic, Financial Literacy and Collaborative Problem

Solving, revised edition. PISA, OECD Publishing, Paris, $2017 \mathrm{~b}$.

Paas, F., Renkl, A., \& Sweller, J. (2004). Cognitive load theory:

Instructional implications of the interaction between information structures and cognitive architecture. Instructional Science, 32, 1-8.

https://doi.org/10.1023/B:TRUC.0000021806.17516.d0

Pitkänen, T., Kokko, K., Lyyra, A. L., \& Pulkkinen, L. (2008). A developmental approach to alcohol drinking behaviour in adulthood: a follow-up study from age 8 to age 42. Addiction, 103, 48-68. https://doi.org/10.1111/j.1360-0443.2008.02176.x 
Ronimus, M., Kujala, J., Tolvanen, A., \&Lyytinen, H. (2014). Children's engagement during digital game-based learning of reading: The effects of time, rewards, and challenge. Computers \& Education, 71, 237-246. https://doi.org/10.1016/j.compedu.2013.10.008

Salemink, K., Strijker, D., \& Bosworth, G. (2017). Rural development in the digital age: A systematic literature review on unequal ICT availability, adoption, and use in rural areas. Journal of Rural Studies, 54, 360-371. https://doi.org/10.1016/j.jrurstud.2015.09.001

Sana, F.; Weston, T. \& Cepeda, N. J. (2013). Laptop multitasking hinders classroom learning for both users and nearby peers. Computers $\&$ Education, 62, 24-31. https://doi.org/10.1016/j.compedu.2012.10.003 Sarsour, K., Sheridan, M., Jutte, D., Nuru-Jeter, A., Hinshaw, S., \& Boyce, W. T. (2011). Family socioeconomic status and child executive functions: The roles of language, home environment, and single parenthood. Journal of the International Neuropsychological Society, 17, 120-132. https://doi.org/10.1017/S1355617710001335

Shochet, I. M., Dadds, M. R., Ham, D., \& Montague, R. (2006). School connectedness is an underemphasized parameter in adolescent mental health: Results of a community prediction study. Journal of Clinical Child \& Adolescent Psychology, 35, 170-179. https://doi.org/10.1207/s15374424jccp3502_1

School District Office of Helsinki (Helsingin kaupungin opetusvirasto) (2016). Helsingin kaupungin opetuksen digitalisaatio-ohjelma vuosille 2016-2019. Koulutuksen ja oppimisen digistrategia. Helsinki, Finland.

Schreiber, J. B., Nora, A., Stage, F. K., Barlow, E. A., \& King, J. (2006). Reporting structural equation modeling and confirmatory factor analysis results: A review. The Journal of Educational Research, 99, 323-338. https://doi.org/10.3200/JOER.99.6.323-338

Sweller, J., Ayres, P., \& Kalyuga, S. (2011). Measuring cognitive load. In Cognitive Load Theory (pp. 71-85). Springer, New York, NY.

Tandon, P. S., Zhou, C., Sallis, J. F., Cain, K. L.,Frank, L. D., \& Saelens, B. E. (2012). Home environment relationships with children's physical activity, sedentary time, and screen time by socioeconomic status. International Journal of Behavioral Nutrition and Physical Activity, 9, 88. https://doi.org/10.1186/1479-5868-9-88

Van Merriënboer, J. J. \& Ayres, P. (2005). Research on cognitive load theory and its design implications for e-learning. Educational Technology Research and Development, 53, 5-13. https://doi.org/10.1007/BF02504793 
Wastiau, P., Blamire, R., Kearney, C., Quittre, V.,Van de Gaer, E., \&

Monseur, C. (2013). The use of ICT in education: a survey of schools in Europe. European Journal of Education, 48, 11-27.

https://doi.org/10.1111/ejed.12020

Wilson, K. A., Bedwell, W. L., Lazzara, E. H., Salas, E., Burke; C. S.,

Estock, J. L., \&Conkey, C. (2009). Relationships between game attributes and learning outcomes: Review and research proposals. Simulation \& Gaming, 40, 217-266.

Yang, Y. T. C. (2012). Building virtual cities, inspiring intelligent citizens:

Digital games for developing students' problem solving and learning motivation. Computers \& Education, 59, 365-377.

https://doi.org/10.1016/j.compedu.2012.01.012

Aino I.L. Saarinen Research Unit of Psychology, University of Oulu, Finland; Faculty of Medicine, University of Helsinki, Finland ORCID ID: http://orcid.org/0000-0003-4495-8360

Jari Lipsanen Faculty of Medicine, University of Helsinki, Finland ORCID ID: http://orcid.org/0000-0003-0746-2745

Mirka Hintsanen Research Unit of Psychology, University of Oulu, Finland

ORCID ID: http://orcid.org/0000-0003-2673-0901

Minna Huotilainen Faculty of Educational Sciences, University of Helsinki, Finland

ORCID ID: http://orcid.org/0000-0002-7251-6984

Liisa Keltikangas-Järvinen Department of Psychology and Logopedics, University of Helsinki, Finland ORCID ID: http://orcid.org/0000-0002-7977-3852

Contact Address: Haartmaninkatu 3, P.O. Box 21, 00014 University of Helsinki, Finland. E-mail: aino.i.saarinen@helsinki.fi 
26 Saarinen et al.,--Digital learning at school

Supplementary Material

\section{Appendix}

The goodness-of-fit statistics for all the models.

\begin{tabular}{ccccccc}
\hline & $\chi^{2}$ value & $d f$ & $p$ & RMSEA & CFI & TLI \\
\hline Scientific literacy & & & & & & \\
Model 1 & 71.400 & 71 & 0.464 & 0.001 & 1.000 & 1.000 \\
Model 2 & 94.377 & 89 & 0.328 & 0.003 & 1.000 & 1.000 \\
Model 3 & 104.835 & 98 & 0.300 & 0.004 & 1.000 & 1.000 \\
Model 4 & 111.320 & 98 & 0.169 & 0.005 & 1.000 & 1.000
\end{tabular}

Mathematical literacy

$\begin{array}{lllllll}\text { Model 1 } & 132.935 & 71 & <.001 & 0.013 & 0.999 & 0.999 \\ \text { Model 2 } & 170.788 & 89 & <.001 & 0.014 & 0.999 & 0.999 \\ \text { Model 3 } & 182.219 & 98 & <.001 & 0.013 & 0.999 & 0.999 \\ \text { Model 4 } & 177.780 & 98 & <.001 & 0.013 & 0.999 & 0.999\end{array}$

Reading literacy

$\begin{array}{lllllll}\text { Model 1 } & 162.957 & 71 & <.001 & 0.016 & 0.999 & 0.999 \\ \text { Model 2 } & 218.350 & 89 & <.001 & 0.017 & 0.998 & 0.998 \\ \text { Model 3 } & 224.626 & 98 & <.001 & 0.016 & 0.998 & 0.998 \\ \text { Model 4 } & 247.120 & 98 & <.001 & 0.017 & 0.998 & 0.998\end{array}$

Collaborative problem-

$\begin{array}{lllllll}\text { Model 1 } & 158.34 & 71 & <.001 & 0.016 & 0.998 & 0.998 \\ \text { Model 2 } & 186.37 & 89 & <.001 & 0.015 & 0.998 & 0.998 \\ \text { Model 3 } & 198.561 & 98 & <.001 & 0.014 & 0.998 & 0.998 \\ \text { Model 4 } & 207.430 & 98 & <.001 & 0.015 & 0.998 & 0.998\end{array}$

RMSEA $=$ the Root Mean Square Error of Approximation. CFI $=$ the Comparative TLI $=$ the Tucker Lewis Index. $N=5037$ 